\title{
Taking the Temperature of Past Ocean Surfaces
}

\section{Dirk Nürnberg}

c limate can vary substantially over millennial time scales; the most prominent examples are the ice ages that have periodically occurred over the past several hundred thousand years. Variations in the heat exchange through the surface layer of the ocean play a key role in these climatic changes. Reliable sea surface temperatures (SST) are therefore crucial to the reconstruction and modeling of past oceanic salinity and density, water column stratification, thermohaline circulation, and ice volume. Particular emphasis has been placed on obtaining records of SSTs during the last ice age because the climatic scenario during the Last Glacial Maximum is often used to test computer models designed to predict forthcoming climatic changes.

On page 1719 of this issue, Lea et al. (1) take a convincing step not only toward accurate SST reconstructions but also to-

\footnotetext{
The author is at GEOMAR, Kiel, Germany. E-mail: dnuernberg@geomar.de
}

ward constraining the timing of surface ocean warming with respect to continental ice sheet melting during deglaciations and deciphering changes in continental ice volume. This is important because in order to understand the causal chains that trigger climate change, leads and lags between different ocean and climate proxies need to be defined. Environmental parameters that lead over others and form "the head of the queue" are likely candidates for initiating and changing climate.

In the late 1970 s to early 1980 s, the Climate/Long-Range Investigation, Mapping, and Prediction Project (CLIMAP) (2) generated the first global SST reconstruction for the Last Glacial Maximum on the basis of the statistical evaluation of changes in microplankton assemblages. The project initiated intense paleoclimate research based on deep-sea sedimentary records. Today, the CLIMAP reconstructions still serve as foundations for paleoclimate research, but many of its results remain controversial, for example, regard- ing the extent of 'sea ice in high latitudes or the relative change in tropical SSTs.

Since CLIMAP, a whole range of approaches for reconstructing SSTs have been developed. Ice core records from equatorial mountains and records of glacial snow line depression suggest that terrestrial temperatures during the Last Glacial Maximum were cooler than during the Holocene by as much as about $5^{\circ} \mathrm{C}$. Noble gas measurements in groundwater also initially implied a $5^{\circ} \mathrm{C}$ glacial temperature drop, although revision of the data led to only a $1.9^{\circ}$ to $2.5^{\circ} \mathrm{C}$ temperature difference. Data from alkenones (a group of temperature-sensitive lipids found in sediments that are used to reconstruct the paleoenvironment) provide evidence for a $2^{\circ}$ to $4^{\circ} \mathrm{C}$ temperature decline of tropical surface waters. A large tropical SST reduction of around $4^{\circ}$ to $5^{\circ} \mathrm{C}$ is also supported by coral records and, recently, by temperature reconstructions based on planktonic oxygen isotope $\left(\delta^{18} \mathrm{O}\right)$ records.

The inconsistencies between the temperature reconstructions mainly result from the heterogeneity of the applied geochemical and micropaleontological methods, which all rely on different assumptions, are used on different types of samples, and have different limitations. For example, the reconstruction of ocean temperatures from stable oxygen isotope ra- 


\section{SCIENCE'S COMPASS}

tios $\left(\delta^{18} \mathrm{O}\right)$ from calcitic microfossil shells is complicated by the fact that the $\delta^{18} \mathrm{O}$ is affected not only by the temperature but also by global ice volume change and evaporation/precipitation effects.

Lea et al. (l) apply the relatively new method of $\mathrm{Mg} / \mathrm{Ca}$ paleothermometry to planktonic protozoans (foraminifera) and measure the stable oxygen isotope ratios $\left(\delta^{18} \mathrm{O}\right)$ of the same specimens. $\mathrm{Mg} / \mathrm{Ca}$ paleothermometry is based on the temperature dependence of the substitution of magnesium into calcium lattice sites. It has long been known that tropical calcitic shells are generally more enriched in magnesium than subpolar shells, but the well-defined exponential dependence of the $\mathrm{Mg} / \mathrm{Ca}$ ratio on temperature within single planktonic foraminiferal species only became clear from systematic core-top investigations covering a wide latitudinal range $(3,4)$ and from species-related cultivating experiments $(5,6)$.

These findings were an exciting step toward a new paleoceanographic tool but were, nevertheless, viewed critically. Indeed, factors other than temperature also affect the amount of magnesium incorporated during foraminiferal shell formation. Interspecies and ontogenetic variations may affect $\mathrm{Mg} / \mathrm{Ca}$ ratios. Preferential removal of relatively soluble magnesium-enriched calcitic parts clearly alters the $\mathrm{Mg} / \mathrm{Ca}$ ratios (7), although recent studies found that during dissolution, $\mathrm{Mg} / \mathrm{Ca}$ and $\delta^{18} \mathrm{O}$ of planktonic foraminiferal shells change proportionally, thus preserving their relation with temperature $(8)$. Small salinity variations exert a small, positively correlated influence on the $\mathrm{Mg} / \mathrm{Ca}$ ratios. Finally, cultivating experiments suggest an inverse relation between $\mathrm{Mg}$ uptake and $\mathrm{pH}$, with higher $\mathrm{Mg} / \mathrm{Ca}$ appearing at lower $\mathrm{pH}$. A postulated increase of 1 salinity unit and $0.2 \mathrm{pH}$ units in the glacial surface ocean (9) would therefore have no substantial influence on $\mathrm{Mg} / \mathrm{Ca}$ because the effects of salinity and $\mathrm{pH}$ on $\mathrm{Mg} / \mathrm{Ca}$ would cancel each other.

Since the initial studies, the $\mathrm{Mg} / \mathrm{Ca}$ paleothermometer has been further calibrated $(6,10,11)$, compared with other temperature proxies (12), and validated in a number of oceanographic settings $(10,12$, 13). The $\mathrm{Mg} / \mathrm{Ca}$ paleothermometer provides an accuracy of about $\pm 0.5^{\circ} \mathrm{C}$ and undoubtedly offers unique advantages compared with other SST proxies. Most importantly, as exploited by Lea et al. (1),

$\mathrm{Mg} / \mathrm{Ca}$ is measured on the same biotic carrier as $\delta^{18} \mathrm{O}$, thereby avoiding the seasonality and/or habitat effects that occur when proxy data from different faunal groups are used (see the figure). The magnitude and timing of SST and $\delta^{18} \mathrm{O}$ changes can thus be separated, and the residual $\delta^{18} \mathrm{O}$ record can be extracted by removing the temperature effect, resulting in a $\delta^{18} \mathrm{O}$
Global ice volume change

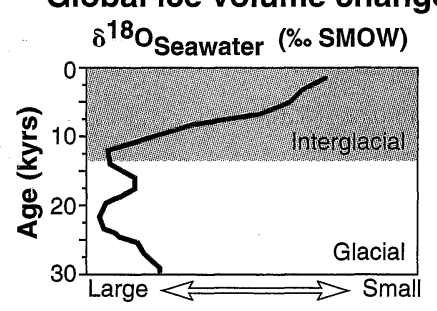

A glimpse into the past. Measuring both stable oxygen isotopes $\left(\delta^{18} \mathrm{O}\right)$ and $\mathrm{Mg} / \mathrm{Ca}$ within planktonic foraminifera (top) allows reliable SSTs to be determined and temporal changes in global ice volume to be assessed (bottom). The foraminiferal $\delta^{18} \mathrm{O}$ signal partly reflects changes in ice volume, because water evaporated from the ocean surface and stored in ice sheets is enriched in ${ }^{16} \mathrm{O}$, thereby changing the ratio between ${ }^{18} \mathrm{O}$ and ${ }^{16} \mathrm{O}$ to heavier values. By independently determining SSTs from $\mathrm{Mg} / \mathrm{Ca}$, the large temperature effect on $\delta^{18} \mathrm{O}$ can be removed, providing the residual $\delta^{18} \mathrm{O}$ signal, which is a direct estimate of the volume of ice stored in continental ice sheets. Comparison of $\mathrm{Mg} / \mathrm{Ca}$ and $\delta^{18} \mathrm{O}$ data from the same biotic carrier shows that ocean surface warming generally precedes the decay of continental ice sheets, suggesting that the surface ocean plays an important role in forcing climate change. Data from or based on (12). Equation from (15). PDB, pee dee belemnite; SMOW, standard mean ocean water; $\%$, per mil.

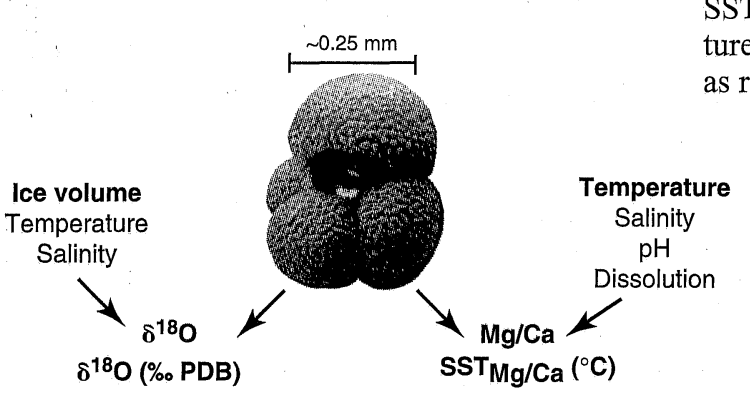

and s revealed by the Vostok deuterium record. The authors also find that the tropical ocean surface waters generally warmed about 3000 to 5000 years before continental ice sheet melting. These observations lead the authors to emphasize the tropical Pacific's role in forcing climate change. A1though local hydrological influences cannot be ruled out, the extracted record of the $\delta^{18} \mathrm{O}$ of seawater is interpreted to be due to changes in global ice volume, and this interpretation is supported by the convincing match between the seawater $\delta^{18} \mathrm{O}$ and past sea-level fluctuations.

Despite the successes in establishing $\mathrm{Mg} / \mathrm{Ca}$ paleothermometry as a tool for reconstructing past ocean temperatures, particularly Lea et al.'s stimulating work, methodological details still need to be defined, and the method must be used in conjunction with other established or new SST proxies. Foraminiferal calcium isotope measurements (14), for example, will most certainly contribute valuable new insights (15).

References and Notes

1. D. W. Lea, D. K. Pak, H. J. Spero, Science 289, 1719 (2000).

2. CLIMAP Project Members, Geol. Soc. Am. Map Chart Ser. MC-36, 1 (1981)

3. D. Nürnberg, J. Foraminifer. Res. 25, 350 (1995).

4. H. Elderfield, R. Rickaby, M. Chapman, M. Greaves, paper presented at the 6th International Conference on Paleoceanology (ICP VI), Lisbon, Portugal, 23 to 28 August 1998.

5. D. Nürnberg, J. Bijma, C. Hemleben, Geochim. Cosmochim. Acta 60, 803 (1996).

6. D. W. Lea, T. A. Mashiotta, H. J. Spero, Geochim. Cosmochim. Acta 63, 2369 (1999).

7. S. J. Brown and H. Elderfield, Paleoceanography 11, 543 (1998).

8. Y. Rosenthal et al., Paleoceanography 15, 135 (2000).

9. A. Sanyal et al., Paleoceanography 11, 513 (1996).

10. T. A. Mashiotta, D. W. Lea, H. J. Spero, Earth Planet. Sci. Lett. 170, 417 (1999).

11. H. Elderfield and G. Gansen, Nature 405, 442 (2000).

12. D. Nürnberg, A. Müller, R. R. Schneider, Paleoceanography 15,124 (2000)

13. D. W. Hastings, A. D. Russell, S. R. Emerson, Paleoceanography 13, 161 (1998)

14. T. F. Nägler, A. Eisenhauer, A. Müller, C. Hemleben, J. Kramers, Geochem. Geophys. Geosyst., in press.

15. N. J. Shackleton, Cent. Nat. Rech. Sci. Colloq. Int. 219, 203 (1974)

16. I am grateful to R. Tiedemann, R. Zahn, and J. Schönfeld for comments. 